\title{
Effects of radiation sterilization on the properties of nonwoven medical devices
}

\author{
(C) Maria S. Lisanevich, ${ }^{*+}$ Reseda Yu. Galimzyanova, and Ildar N. Musin \\ Department of Medical Engineering. Kazan National Research Technological University. \\ Karl Marx St., 68. Kazan, 420015. Republic of Tatarstan. Russia.E-mail: lisanevichm@gmail.com
} \begin{abstract}
Keywords: nonwoven material, spunmelt material, low-temperature plasma, consumer indicators.
\end{abstract}
*Supervising author; ${ }^{+}$Corresponding author

\begin{abstract}
Currently, there is a tendency for a significant increase in production and expansion of areas of application of nonwoven materials (NM), which are used in almost all areas of human life. Such properties of NMs as hydrophilicity or hydrophobicity, air permeability, good barrier and strength indicators at a relative low cost allow them to be effectively used for medical purposes. Nonwovens for medical use (NMMN) are considered. The most important stage in the final processing of medical devices made of NM is radiation sterilization. The influence of the absorbed dose and the type of ionizing radiation on the properties of NMMN of various designs: obtained by spunlace technology, by spunbond-meltblown-spunbond technology, and laminated nonwoven material has been studied. As a result of the conducted research, it was recommended: to sterilize NM with an electron beam, to control the consumer properties of medical devices from NM to check the quality of products after sterilization by assessing the change in the strength index with elongation, additionally to assess for laminated NM - water resistance, spunlace - absorption. In the production of nonwoven materials, various polymers are used, which have correspondingly different resistance to radiation sterilization. Some materials, for example, based on polypropylene, degrade when exposed to radiation, and the level of technical characteristics of the material is significantly reduced. It is also possible for autooxidative reactions initiated by radiation to occur in polymers, which can continue for a long time after irradiation of articles. To use these materials in radiation sterilized medical devices, it is necessary to have an understanding of the effect of ionizing radiation in a wide range of sterilizing doses on the materials used in these devices.
\end{abstract}

\section{References}

[1] A.S. Alimov. Practical application of electron accelerators. SINP MSU Preprint No.2011-13/877. Moscow. 2011. (russian)

[2] D.P. Grechukhin. Gamma radiation. Physical encyclopedia. D.M. Alekseev, A.M. Baldin, A.M. BonchBruevich, A.S. Borovik-Romanov and others; under total. ed. A.M. Prokhorov. Moscow: Soviet encyclopedia. 1988-1999. (russian)

[3] Sterilization methods and their effects on medical equipment containing electronics System requirements: AdobeAcrobatReader. URL: http://www.elin.ru/files/pdf/Thermochron/AN5068_RU.pdf (date of access: 02/29/2014).

[4] Sources of ionizing radiation [Electronic resource]. URL: http://spdepartment.ru/for_students/online_education/course.phpCOURSE_ID=2\&LESSON_ID=35 (date of access: 02.02 .2014$)$.

[5] V.S. Ivanov. Radiation chemistry of polymers: textbook for universities. Leningrad: Chemistry. 1988. 320p. (russian)

[6] Yu.N. Khakimullin, A.R. Bakhridinova, R.R. Shaimardanova, M.S. Lisanevich, R.Yu. Galimzyanova. The effect of radiation sterilization on the properties of spunmelt materials. Bulletin of the Technological University. 2015. Vol.18. No.1. P.251-253. (russian)

[7] Yu.N. Khakimullin, M.S. Lisanevich, R.Yu. Galimzyanova, B.L. Shakirov. Prediction of the durability of a laminated nonwoven material sterilized by ionizing radiation. Bulletin of the Technological University. 2015. Vol.18. No.17. P.120-122. (russian)

[8] Yu.N. Khakimullin, E.R. Rakhmatullina, R.Yu. Galimzyanova, M.S. Lisanevich, I.E. Kogenman, R.S. Yarullin. The possibility of obtaining nonwovens resistant to traditional methods of sterilization in the 

conditions of modern production. Vestnik Kazan Technological University. 2013. Vol.16. No.23. P.118120. (russian)

[9] M.S. Lisanevich, K.V. Legaeva, E.E. Tsareva, R.Yu. Galimzyanova, I.N. Musin, Yu.N. Khakimullin. Predicting the durability of sterilized nonwoven fabrics produced using spunlace technology. Bulletin of Kazan Technological University. 2014. Vol.17. No.14. P.144-146. (russian)

[10] R.Yu. Galimzyanova, B.L. Shakirov, I.E. Kogenman, L.S. Travkina, M.S. Lisanevich, Yu.N. Khakimullin. Influence of radiation sterilization on the properties of two-layer laminated nonwoven fabric. Vestnik Kazan Technological University. 2014. Vol.17. No.14. P.194-196. (russian)

[11] Yu.N. Khakimullin, K.V. Legaeva, E.S. Kuznetsova, L.S. Travkina, M.S. Lisanevich, R.Yu. Galimzyanova. Influence of radiation sterilization on the properties of nonwoven fabric obtained by spunlace technology. Bulletin of Kazan Technological University. 2014. Vol.17. No.14. P.150-153. (russian)

[12] R.Yu. Galimzyanova, Yu.D. Shakirova, M.S. Lisanevich, Yu.N. Khakimullin, A.P. Zhanzhora. Influence of gamma and electron radiation during radiation sterilization on the properties of a material based on viscose fiber. Bulletin of the Technological University. 2016. Vol.19. No.10. P.99-101. (russian)

[13] A.E. Tsarev, M.S. Lisanevich. Investigation of the effect of radiation sterilization on the electrostaticity of nonwoven spunmelt materials for medical use. In the collection: Fundamental and applied problems of creating materials and aspects of technologies for the textile and light industry. Collection of articles All-Russian scientific and technical conference. under. ed. L.N. Abutalipova. 2019. P.47-50. (russian)

[14] R.Yu. Galimzyanova, E.R. Rakhmatullina, M.S. Lisanevich, Yu.N. Khakimullin. Influence of radiation sterilization on the physical and mechanical properties of polypropylene-based nonwoven fabric.

Bulletin of the Technological University. 2020. Vol.23. No.2. P.19-23. (russian)

[15] Process for the production ofa gamma-radiation resistant polypropylenefibre for a radiation sterilizable non-woven fabric: пат. ЕP 0667406 A1 European patent: EP19950300857. Makipirttisimo [FI]; Bergholmheikki [FI]; заявитель Suominen Oy J. W. [FI]; заявл. 13.02.95; опубл. 16.08.96.

[16] E.R. Rakhmatullina, M.S. Lisanevich, R.Yu. Galimzyanova, Yu.N. Khakimullin, N.A. Mukmeneva. Influence of processing conditions on the properties of polypropylene Deformation and destruction of materials. 2017. No.12. P.35-39. (russian)

[17] M.S. Lisanevich, R.Yu. Galimzyanova, Yu.N. Khakimullin, E.R. Rakhmatullina. Influence of the absorbed dose of radiation exposure on the destruction of polypropylene, depending on the location of the sample to the electronic emitter. Vestnik Technological University. 2019. Vol.22. No.11. P.36-38. (russian)

[18] M.S. Lisanevich, R.Yu. Galimzyanova, N.A. Mukmeneva, Yu.N. Khakimullin, E.R. Rakhmatullina, E.V. Khusnutdinova, D.S. Sirazetdinov, I.I. Garipov. Investigations of the radiation resistance of a block copolymer of propylene and ethylene and the possibility of its increase. Vestnik Technological University. 2018. Vol.21. No.10. P.100-103. (russian)

[19] M.S. Lisanevich, R.Yu. Galimzyanova, N.A. Mukmeneva, Yu.N. Khakimullin, E.R. Rakhmatullina, E.S. Kuznetsova, A.N. Ramazanova. The use of phenolic and mixed phenol-phosphite antioxidants for anti-radiation protection of medical polypropylene. Vestnik Technological University. 2015. Vol. 18. No.2. P.181-182. (russian)

[20] E.R. Rakhmatullina, R.Yu. Galimzyanova, M.S. Lisanevich, E.S. Kuznetsova, Yu.N. Khakimullin, N.A. Mukmeneva. The influence of stabilizers on the properties of medical compositions based on polypropylene. Vestnik Kazan Technological University. 2013. Vol.16. No.22. P.181-183. (russian)

[21] A.N. Ramazanova, M.S. Lisanevich, R.Yu. Galimzyanova, Yu.N. Khakimullin. Development of a radiation-resistant polymer composition for medical purposes based on polypropylene copolymers In the collection: Human health in the XXI century IX-th Russian scientific-practical conference: collection of scientific articles. 2017. P.381-383. (russian)

[22] E.R. Rakhmatullina, R.Yu. Galimzyanova, M.S. Lisanevich, S.M. Khurmatulina, S.A. Fedotov, Yu.N. Khakimullin. Investigation of the effect of nano-additives and mixing time on the properties of compositions based on polypropylene In the collection: Human health in the XXI century IX-th Russian scientific-practical conference: collection of scientific articles. 2017. P.383-387. (russian) 